\title{
Postnatal Expression of Bone Morphogenetic Proteins and Their Receptors in the Mouse Testis
}

\author{
I. M. CILLER ${ }^{1 *}$, S. K. A. PALANISAMY ${ }^{{ }^{*}}$, U. A. CILLER ${ }^{1}$, J. R. MCFARLANE $^{\mathbf{1}}$ \\ *These authors contributed equally to this work. \\ ${ }^{1}$ Centre for Bioactive Discovery in Health and Ageing, School of Science and Technology, \\ University of New England, Armidale, Australia
}

Received September 18, 2015

Accepted December 11, 2015

On-line March 15, 2016

\section{Summary}

TGF- $\beta$ superfamily members including bone morphogenetic proteins (BMPs) and their receptors (BMPR-1A, $-1 B$ and -2 ) have been shown to be important for reproductive function in both males and females, while information on the role of BMPs in males is limited. Functional studies on select BMPs and BMP receptors have demonstrated vital roles for these proteins in somatic and germ cell proliferation, steroidogenesis and overall fertility. In order to gain insight into the importance of these genes during postnatal reproductive development in males, our study was undertaken to specify the distribution of BMP and BMPR mRNA in male reproductive and steroidogenic tissues and quantify these genes in the testis using the mouse as our model. We screened testis at two, four, six and eight weeks of age for the expression of ten BMPs and three BMP receptors using RT-qPCR. All three BMP receptor mRNAs - Bmpr1a, Bmpr1b and Bmpr2, and ten BMP mRNAs - Bmp2, Bmp3, Bmp3b, Bmp4, $B m p 5, B m p 6, B m p 7, B m p 8 a, B m p 8 b$ and $B m p 15$ were expressed in mouse testis at all stages screened. Testicular expression of genes varied within age groups and at specific developmental stages. Our study establishes an extensive BMP system in mouse reproductive and steroidogenic tissues.

\section{Key words}

Male reproduction - Growth factors - Bone morphogenetic proteins • Testis

\section{Corresponding author}

I. M. Ciller, Centre for Bioactive Discovery in Health and Ageing, School of Science and Technology, University of New England, Armidale, NSW 2351, Australia. E-mail: imc.armidale@gmail.com

\section{Introduction}

Bone morphogenetic proteins (BMPs) belong to the decapentaplegic-Vg-related (DVR) family, which forms the largest subgroup of growth factors in the transforming growth factor- $\beta$ (TGF- $\beta$ ) superfamily (McDonald and Hendrickson 1993). BMP signaling occurs via heterodimerization of type I (BMPR-1A, BMPR-1B) and type II (BMPR-2) serine/threonine receptors (Koenig et al. 1994, Ebisawa et al. 1999), which activate SMAD1, SMAD5 and/or SMAD8 signal transducers (Hoodless et al. 1996, Liu et al. 1996, Nishimura et al. 1998, Aoki et al. 2001, Kersten et al. 2005). Reproductive functions of BMPs and their putative receptors in males include the modulation of testosterone synthesis (Teixeira et al. 1999), germ cell maturation (Zhao et al. 1998), sperm quality (Hu et al. 2004), integrity of reproductive tissues ( $\mathrm{Hu}$ et al. 2004, Zhao et al. 1998) and epithelial secretory function (Settle et al. 2001).

In mice, knockouts for Bmprla (Alk-3) and Bmpr2 are embryonically fatal (Mishina et al. 1995, Beppu et al. 2000), while Bmprlb (Alk-6) deficiency leads to infertility in males and females (Yi et al. 2001). In male mice Bmprlb deficiency resulted in compromised fertility attributed to defective development of the seminal vesicles (Yi et al. 2001). Seminal vesicles have been shown to express Bmprla and Bmprlb mRNA in immature mice (Settle et al. 2001), however, whether these mutants had altered testicular function has not been reported. On the other hand, partial dysfunction of 
Bmpr $1 b$ as seen in the Booroola merino strain of sheep results in significantly fewer primordial follicles (Ruoss et al. 2009) yet higher ovulation rate in females and no apparent effects in males (Piper and Bindon 1982, Wilson et al. 2001).

Expression of mutant Bmp4 (Hu et al. 2004), Bmp7 (Zhao et al. 2001), Bmp8a (Zhao et al. 1998) and Bmp8b (Zhao et al. 1996) resulted in either compromised fertility or infertility in male mice, while Bmp15 null male mice were reported to have normal fertility (Yan et al. 2001). Bmp2, Bmp4, Bmp5, Bmp6, Bmp7, Bmp8a, Bmp8b and Bmprla have been shown to be expressed in embryonic mouse testis (Dewulf et al. 1995, Ross et al. 2007). Mouse mRNA expression of Bmp2 and Bmp 4 was detected in immature testis (Itman and Loveland 2008), Bmp7, Bmp8a and Bmp8b in immature and adult testis (Zhao et al. 1998, 2001, Itman and Loveland 2008), Bmp5 and Bmp6 in adult testis (Lyons et al. 1989, Marker et al. 1997), while in adult mouse testis Bmp15 mRNA and Bmp3b (Gdf10) were reported to be absent (Dube et al. 1998, Katoh and Katoh 2006).

Findings about the expression of BMP receptor mRNAs in the mouse testis or cells derived thereof have been inconclusive, perhaps due to assay sensitivity. Pellegrini et al. (2003), Dewulf et al. (1995) and ten Dijke et al. (1994) reported not finding Bmprlb mRNA in mouse testis using Northern blotting and in situ hybridization, while Gouedard et al. (2000) reported Bmprlb expression in mouse testis and testicular cell lines MA-10 cells and SMAT-1 cells derived from Leydig cell tumors and immature Sertoli cells respectively using polymerase chain reaction (PCR). In Sertoli cells of immature mice Puglisi et al. (2004) detected Bmprla using the Ribonuclease Protection Assay and Bmpr2 expression by Northern blot, while on the contrary Pellegrini et al. (2003) did not readily detect the same mRNAs in Sertoli cells. In spermatogonia of immature mice Pellegrini et al. (2003) identified BMPR-IA protein and Bmprla and Bmpr2 transcripts using Northern blot, and while Puglisi et al. (2004) also found Bmprla expressed in spermatogonia, they did not detect Bmpr2.

Pellegrini et al. (2003) demonstrated that BMP-4 increased proliferation of spermatogonia while its transcripts were expressed by Sertoli cells but not germ cells, indicating BMP-4 had a paracrine function in germ cell signaling. Bmp4 expression decreased progressively from postnatal day 4 to 17 (Pellegrini et al. 2003). In mice before 3 weeks of age Bmp $8 a$ and $B m p 8 b$ mRNAs have been detected in spermatogonia and spermatocytes and at 3 weeks Bmp8a and Bmp8b mRNAs were localized in stage 6-8 round spermatids, demonstrating a development shift (Zhao and Hogan 1996, Zhao et al. 1996). Bmp $8 b$ homozygous mutants had greater germ cell degeneration than Bmp8a mutants, additionally homozygous $B m p 8 b^{\text {tmlblh }}$ mutant mice exhibited progressive depletion of germ cells due to increased germ cell apoptosis and were rendered infertile (Zhao et al. 1996, 1998), indicating a function in germ cell survival and maintenance.

As significant roles for BMPs and their receptors are emerging in male reproductive function, the aim of this study was to investigate the distribution of these genes in adult reproductive and steroidogenic tissues using RT-PCR and quantify the relative gene expression of BMP receptors - Bmprla, Bmprlb and Bmpr2, and BMPs - Bmp2, Bmp3, Bmp3b, Bmp4, Bmp5, Bmp6, Bmp7, Bmp8a, Bmp8b and Bmp15 in the mouse testis at two, four, six and eight weeks of age using reverse transcription quantitative PCR (RT-qPCR) analysis of mRNA. By examining the expression profiles of $\mathrm{BMP} / \mathrm{BMP}$ receptor $\mathrm{mRNAs}$ at four specific time points we provide greater clarity to what functions individual genes may serve at specific developmental stages, as well as providing comparisons between different genes to enhance understanding of relative abundance and how that may affect normal physiology of the testis.

\section{Methods}

\section{Animals}

The University of New England Animal Ethics Committee authorized the use of animals needed to conduct this research, which was in accordance with the National Health and Medical Research Council: Australian code of practice for the care and use of animals for scientific purposes 7th Edition 2004. Male Swiss Quackenbush mice (Physiology Animal House, University of New England, NSW, Australia) were housed in sanitary conditions in a light controlled room (12:12) at a constant temperature of $21^{\circ} \mathrm{C}$ and had access to a constant supply of standard rodent chow and water.

At the age of 2, 4, 6 and 8 weeks mice were sacrificed by asphyxiation with $\mathrm{CO}_{2}$ and approximately $100 \mathrm{mg}$ testis placed in RNALater (Ambion, Austin, TX) and incubated at $4{ }^{\circ} \mathrm{C}$ overnight and then stored at $-80^{\circ} \mathrm{C}$ until RNA extraction. Epididymis, vas deferens, seminal vesicles, coagulating gland, prostate, adrenal gland and 
visceral adipose tissue of mature mice were also collected for RNA extraction and processed as for testis. Seminal vesicle and testis weights of mice sacrificed weekly from 2 to 8 weeks of age were measured to have a biological indicator of reproductive development. At 2 weeks mice were considered immature, at 4 weeks early pubertal, at 6 weeks late pubertal and at 8 weeks mature. $\mathrm{N}=5$.

\section{RNA extraction, RT PCR and $q P C R$}

RNA was extracted using TRI Reagent (SigmaAldrich Co, St. Louis, MO) according to manufactures instructions. RNA integrity was checked on a $1 \%$ RNA agarose gel (CSBC 2011) and quantified using a Nanodrop ND-1000 spectrophotometer (Thermo Fisher Scientific, Inc., Wilmington, DE).

Reverse transcription was performed by annealing $2 \mu \mathrm{g}$ of total RNA with $20 \mathrm{ng}$ Oligo(dT) ${ }_{15}$ Primer (Fisher Biotec, Subiaco, WA) at $70{ }^{\circ} \mathrm{C}$ for $5 \mathrm{~min}$ and then placed on ice. This was followed by extension carried out at $40{ }^{\circ} \mathrm{C}$ for 60 min using $10 \mathrm{mM}$ dNTP Mix (Fisher Biotec), 1 x RT Buffer, 400 U MMLV Reverse Transcriptase (Promega, Alexandria, NSW) and $1 \mathrm{U}$ rRNasin(R)RNase Inhibitor (Promega).

Gene specific primers (Table 1) (GeneWorks Pty Ltd, Hindmarsh, SA) were designed using NCBI PrimerBLAST (Ye et al. 2009). A routine PCR using $80 \mathrm{ng}$
cDNA was carried out to confirm the specificity of primers and their expected product lengths were checked using $2 \%$ agarose gel electrophoresis to confirm the presence and amplification of the gene of interest. The PCR products were gel eluted and sequenced at Ramachiotti Centre for Genomics, UNSW, Sydney for confirmation.

Quantitative PCR (qPCR) reactions were set up in duplicate using $16 \mathrm{ng}$ cDNA, in Fast EvaGreen qPCR Mix (Biotium, Hayward, CA) using a CAS-1200 automated PCR Setup robot (Corbett Robotics, Eight Mile Plains, QLD) and qPCR performed using a RotorGene R6 6000 Real-time Analyzer (Corbett Life Science, Concord, NSW).

\section{Data analysis}

Data analysis of qPCR Ct values was performed by the $2^{-\Delta \Delta \mathrm{Ct}}$ method using $\beta$-actin as the reference gene. Statistical analysis was performed using a general linear model procedure in SAS statistical software (SAS Institute Inc., Cary, NC, USA). The data were evaluated using one-way ANOVA followed by the StudentNewman Keuls post hoc test. Values were considered to be significantly different at $\mathrm{P}<0.05$ and presented as mean \pm standard error (SE).

Table 1. The forward and reverse primer sequences used for qPCR.

\begin{tabular}{|c|c|c|c|c|}
\hline Gene & $\begin{array}{l}\text { NCBI } \\
\text { reference \# }\end{array}$ & Forward primer $\left(5^{\prime} \rightarrow 3^{\prime}\right)$ & Reverse primer $\left(5^{\prime} \rightarrow 3^{\prime}\right)$ & $\begin{array}{l}\text { Amplicon } \\
\text { length (bp) }\end{array}$ \\
\hline$\beta$-actin & NM_007393.3 & CGTCGACAACGGCTCCGGCATG & TGGGCCTCGTCACCCACATAG & 150 \\
\hline Bmprla & NM_009758.4 & AGGTCAAAGCTGTTCGGAGA & CTGTACACGGCCCTTTGAAT & 178 \\
\hline Bmprlb & NM_007560.3 & TCAATGTCGTGACACTCCCATTCCT & TGCTGTACCGAGGTCGGGCT & 245 \\
\hline Bmpr2 & NM_007561.3 & CACCCСCTGACACAACACCACTC & GACCCCGTCCAATCAGCTCCAG & 243 \\
\hline Bmp2 & NM_007553.2 & ACCCCCAGCAAGGACGTCGT & AAGAAGCGCCGGGCCGTTTT & 197 \\
\hline Bmp3 & NM_173404.3 & AGCAGTGGGTCGAACCTCGGA & ACCCCCACCGCTCGCACTAT & 199 \\
\hline Bmp $3 b$ & NM_145741.2 & GGCAACACCGTCCGAAGCTTCC & AGGAGGCGGCAGGATGCGTT & 199 \\
\hline Bmp 4 & NM_007554.2 & GACTACTGGACACCAGACTAGTCC & CTTCCCGGTCTCAGGTATCA & 180 \\
\hline Bmp5 & NM_007555.3 & ATCAGGACCCCTCCAGGATGCC & TGATCCAGTCCTGCCATCCCAGATC & 120 \\
\hline Bmp6 & NM_007556.2 & GCAGAGTCGCAACCGGTCCA & GGTGCAATGATCCAGTCCTGCC & 153 \\
\hline Bmp7 & NM_007557.2 & CAAGCAGCGCAGCCAGAATCG & CAATGATCCAGTCCTGCCAGCCAA & 161 \\
\hline Втр8а & NM_007558.2 & TTGGCTGGCTGGACTGGGTCA & GCTGTCATAGTACAGCACAGAGGTG & 209 \\
\hline Bmp $8 b$ & NM_007559.4 & GGCTGGCTGGACTCTGTCATTGC & AGCTCAGTAGGCACACAGCACAC & 176 \\
\hline Bmp 15 & NM_009757.4 & GCCGTCGGCCAACACAGTAAG & AGAAGGTAAGTGCTTGGTCCGGCA & 202 \\
\hline
\end{tabular}




\section{Results}

\section{Testis and seminal vesicle weight}

As a measure of reproductive development we measured testis and seminal vesicle (SV) weight in 2- to 8-week-old mice as shown in Figure 1 panel A and B. Testis and SV weight increased significantly $(\mathrm{P}<0.05)$ on a weekly basis from 2 weeks to 7 weeks at which time point weight had plateaued and was no longer significantly different at 8 weeks.

\section{Comparative analysis of BMP receptor gene expression}

The relative changes in the BMP receptor gene expression at the 4 time points examined are shown in Figure 2. Bmpr2 and Bmprla were the most abundant genes at all ages tested, while Bmprlb was expressed in considerably lower amounts. Overall the pattern of change with age was similar in all three receptors with a marked decline in expression at 4 weeks followed by a slight rise at 8 weeks. At 2 weeks Bmprla expression was relatively high at $60.3 \pm 12 \%$, while at 4 weeks Bmprla expression had been reduced 23 fold $(\mathrm{P}=0.0003)$ and continued to decline although not significantly to six weeks. By 8 weeks Bmprla significantly increased by 2 fold ( $\mathrm{P}=0.016)$ over the expression at 6 weeks (Fig. 2). At 2 weeks of age Bmpr $1 b$ was expressed at significantly lower amounts $(1.4 \pm 0.4 \%)$ than either Bmprla $(60.3 \pm 12 \%)$ or Bmpr2 (295 $\pm 75 \%)$. The drop in expression level at 4 and 6 weeks from 2 weeks of age was also much higher (182 and 255 fold) than the decline seen with Bmprla but similar to that observed with Bmpr2. The expression of Bmpr2 was the highest of the 3 receptors at 2 weeks $(296 \pm 75 \%)$, and followed a similar expression pattern with age as did Bmprlb, with a large drop at 4 weeks and remaining low at 6 weeks followed by a slight but significant rise $(\mathrm{P}<0.0001)$ at 8 weeks.

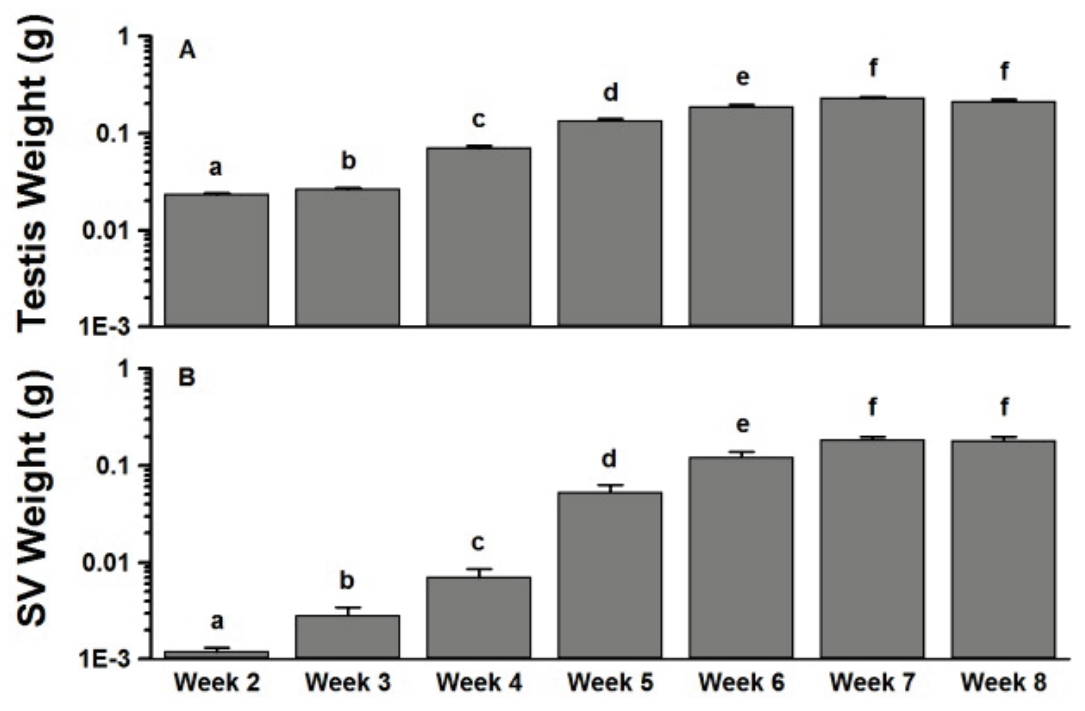

Fig. 1. (Panel A) Testis and (Panel B) seminal vesicle weights (g) for mice aged 2, 3, 4, 5, 6, 7 and 8 weeks. Results expressed as Mean \pm SE $\quad(n=5)$ Different superscripts denote different levels of significance $(P<0.05)$.

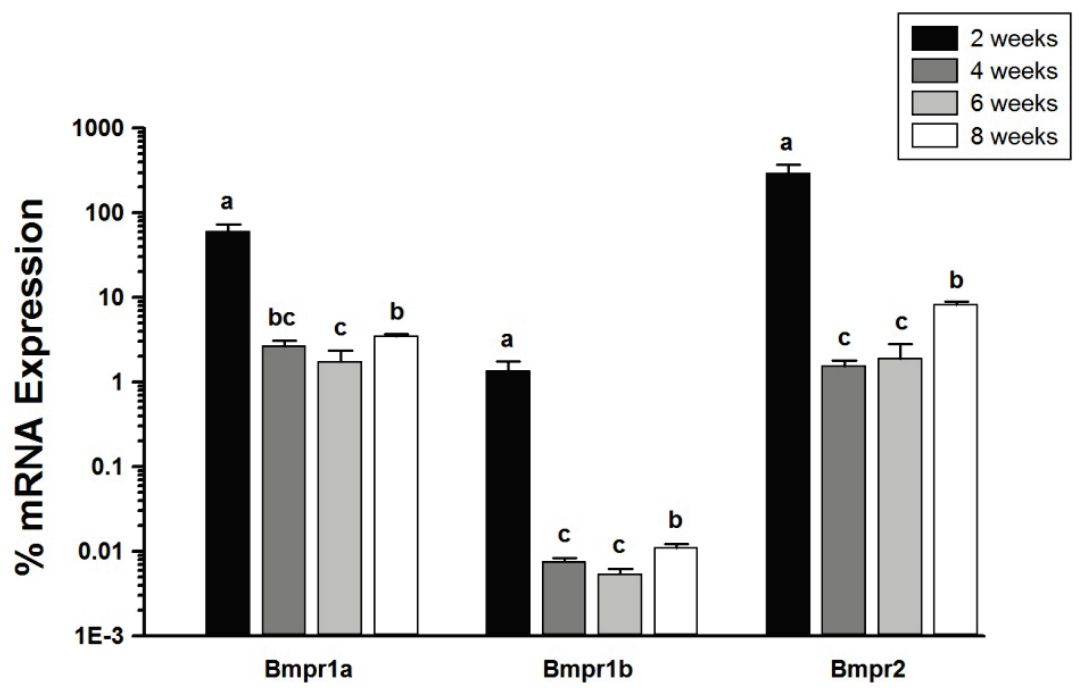

Fig. 2. Bmpr1a, Bmpr1b and Bmpr2 expression in testis for mice aged 2, 4, 6 and 8 weeks. Results were calculated as a percentage of the housekeeping gene $\beta$-actin and presented as Mean \pm SE $(n=5$ in duplicate). Different superscripts denote different levels of significance $(P<0.05)$ of individual genes throughout postnatal development. 


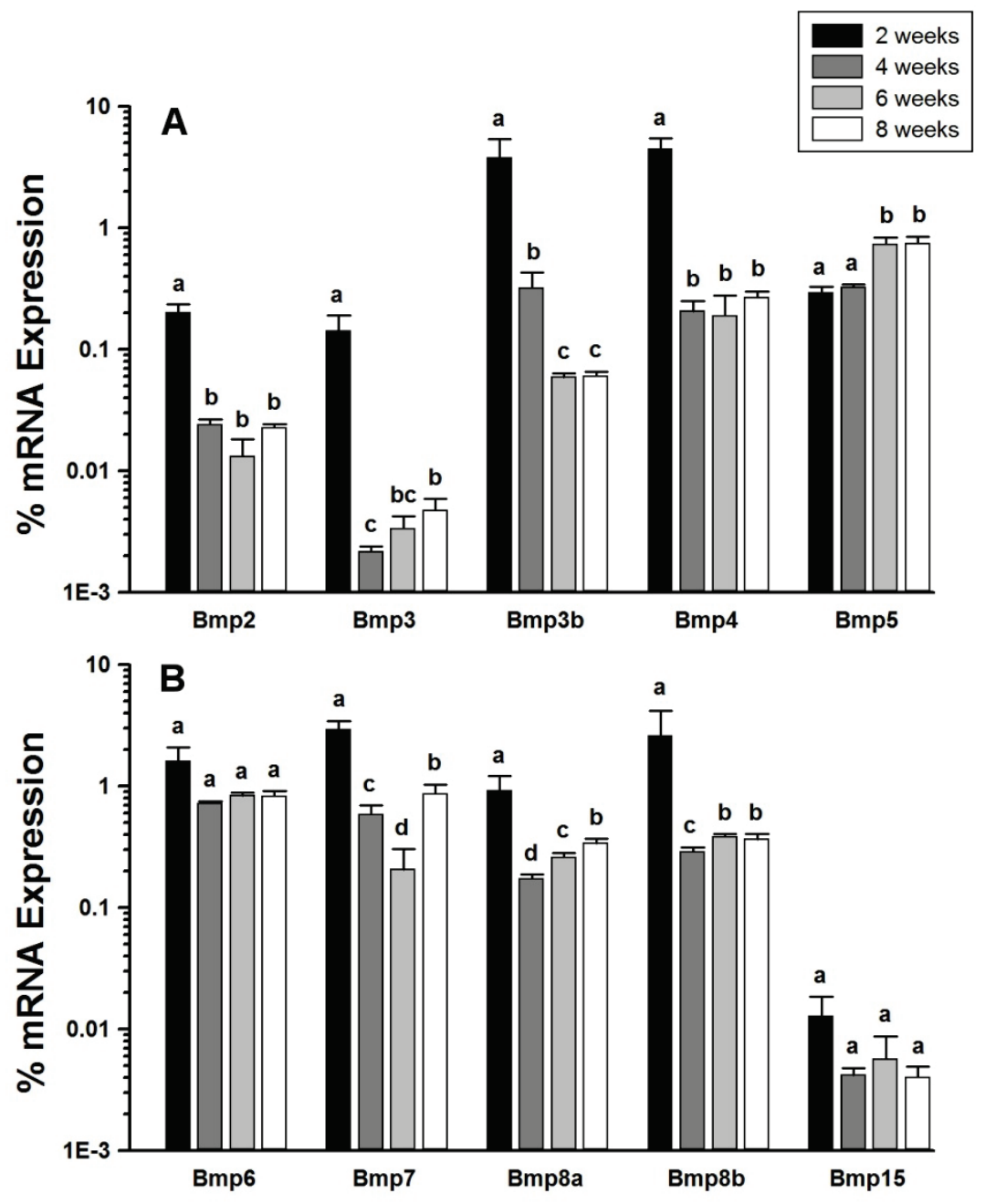

Fig. 3. (Panel A) $B m p 2, \quad B m p 3$, $B m p 3 b, B m p 4$ and $B m p 5$, (Panel B) Bmp6, Bmp7, Bmp8a, Bmp8b and Bmp15 mRNA levels in testis for mice aged 2, 4, 6 and 8 weeks. Results were calculated as a percentage of the housekeeping gene $\beta$-actin and presented as Mean \pm SE $(n=5$ in duplicate). Different superscripts denote different levels of significance $(P<0.05)$ of individual genes throughout postnatal development.

Comparative analysis of BMP gene expression in mouse testis during postnatal development

The relative changes in BMP gene expression at the 4 time points examined are shown in Figure 3 panel $A$ and B. With the exception of Bmp5 all genes reduced their expression from 2 to 4 weeks. Bmp 15 was the least expressed gene at 2 weeks. Genes that significantly increased their expression from 4 to 8 weeks were $B m p 3$, Bmp5, Bmp7, Bmp $8 a$ and Bmp8b. Genes that did not change significantly from 4 to 8 weeks were $B m p 2$, Bmp4, Bmp6 and Bmp15, while Bmp3b was the only gene to significantly decrease its expression by 8 weeks. At 4 weeks $B m p 3 b$ was reduced by 12 fold $(\mathrm{P} \leq 0.04), B m p 4$ by 22 fold $(\mathrm{P} \leq 0.0007), B m p 7$ by 5 fold $(\mathrm{P}=0.0008)$, Bmp $8 a$ by 5 fold $(\mathrm{P} \leq 0.02)$ and $\mathrm{Bmp} 8 \mathrm{~b}$ by 9 fold $(\mathrm{P}=0.0463)$, while $B m p 2$ was reduced 8 fold to less than $0.1 \%(\mathrm{P} \leq 0.0001)$, and $B m p 3$ was reduced 65 fold to less than $0.01 \%$ were $\mathrm{P}=0.009$. Bmp3 expression declined the most radically of all the BMP mRNAs becoming the least expressed gene. By 6 weeks Bmp5, Bmp $8 a$ and $B m p 8 b$ significantly increased their expression were $\mathrm{P} \leq 0.0001$,
$\mathrm{P}=0.003$ and $\mathrm{P} \leq 0.004$ respectively, and Bmp3b and Bmp7 expression reduced significantly were $\mathrm{P} \leq 0.03$ and $\mathrm{P}=0.02$ respectively from 4 weeks. Expression of Bmp2, Bmp3, Bmp4, Bmp6 and Bmp15 did not alter and Bmp3 remained the least expressed gene. At 8 weeks expression of Bmp7 and Bmp8a increased by 4 fold $(\mathrm{P} \leq 0.005)$ and 1 fold $(\mathrm{P}=0.04)$ respectively. Expression of Bmp2, Bmp3, Bmp3b, Bmp4, Bmp5, Bmp6, Bmp8b and Bmp15 did not change, however Bmp15 was the least expressed gene at 8 weeks, being expressed at only $0.004 \%$ of the housekeeping gene.

Bmp receptor and bmp screening in male reproductive and steroidogenic tissues

Having detected mRNA expression of Bmprla, Bmpr1b, Bmpr2, Bmp2, Bmp3, Bmp3b, Bmp4, Bmp5, Bmp6, Bmp7, Bmp8a, Bmp8b and Bmp 15 in mouse testis, we examined the expression of these genes in the epididymis, vas deferens, seminal vesicles, coagulating gland, prostate, adrenal gland and visceral adipose tissue of adult mice (Fig. 4). All genes were detected in all 
tissues screened with the exception of Bmp3 and Bmp5 in vas deferens of which expression was too low to detect.

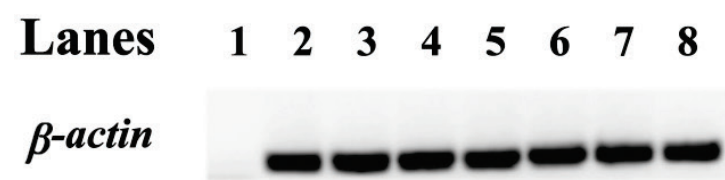

Bmpr1a

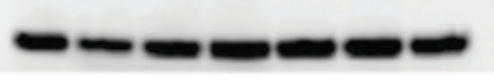

Bmpr1b

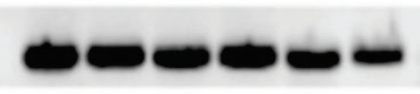

Bmpr2

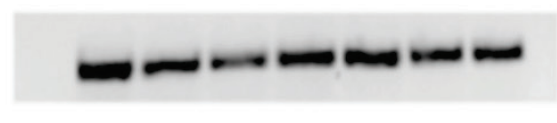

$B m p 2$

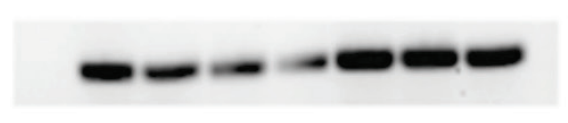

Bmp3

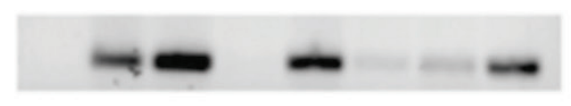

Bmp3b

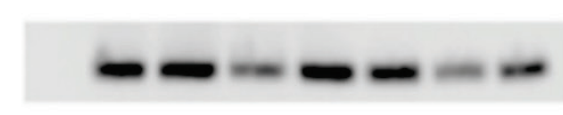

\section{Bmp4}

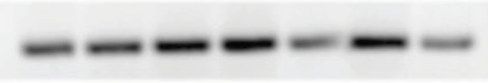

Bmp5

\section{Bmp6}

$\operatorname{Bmp} 7$

\section{Bmp8a}

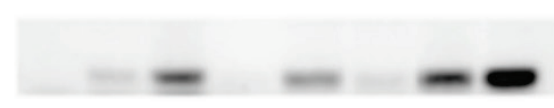

Bmp8b
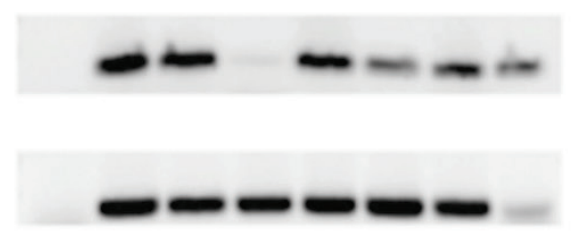

\section{Bmp15}

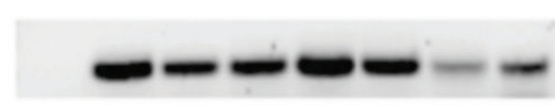

Fig. 4. $B M P$ receptor (Bmpr1a, Bmpr1b, Bmpr2) and $B M P(B m p 2$, Bmp3, Bmp3b, Bmp4, Bmp5, Bmp6, Bmp7, Bmp8a, Bmp8b, Bmp15) mRNA expression in adult male reproductive and steroidogenic tissues. Lane: $1=$ Negative control, $2=$ Epididymis, 3 = Vas deferens, $4=$ Seminal vesicle, $5=$ Prostate, $6=$ Coagulating gland, $7=$ Adrenal gland, $8=$ Adipose tissue

\section{Discussion}

We have demonstrated that there is widespread expression of BMPs and BMP receptors in male reproductive and steroidogenic tissues, which included finding testicular expression of Bmpr1b, Bmpr2, Bmp3, Bmp3b, Bmp4, Bmp5, Bmp6 and Bmp15 at all developmental stages. It is likely that Bmpr $1 b$ mRNA had been reported absent in mouse testis by numerous researchers (ten Dijke et al. 1994, Dewulf et al. 1995, Pellegrini et al. 2003) with one exception (Gouedard et al. 2000), because its expression is low both relative to the housekeeping gene and to Bmprla and Bmpr2 as determined in this study using highly sensitive RT-qPCR. This is supported in part by Belville et al. (2005) who found that Bmprlb was expressed at a significantly lower level than Bmprla in SMAT-1 cells. We found Bmprla and Bmpr2 mRNA in relatively high levels at all developmental stages, however BMP receptor expression was significantly higher in immature animals than in adult animals. Similarly, Puglisi et al. (2004) reported that Bmprla and Bmpr2 expression in the testis decreased significantly with age, however they were unable to detect Bmpr 2 mRNA by 30 days of age ( $\sim$ weeks) or older. Given that Bmpr2 was one of the most abundant genes tested in our study the reason for this discrepancy is unclear.

Bmp2, Bmp 4 and Bmp7 mRNAs were present at all ages screened but had their highest expression in immature testis. Itman and Loveland (2008) reported Bmp2, Bmp4 and Bmp7 mRNA in 5-day-old mouse testis, and demonstrated that BMP-2 and BMP-4 treatment stimulated signaling of SMAD 1, 5 and 8 in Sertoli cell and spermatogonial cultures. Furthermore, BMP-2 had a role in the proliferation of spermatogonia in concert with FSH but not alone, and BMP-7 had a role in the proliferation of Sertoli cells in the presence of FSH (Puglisi et al. 2004), while BMP-4 increased proliferation of spermatogonia independent of gonadotrophins (Pellegrini et al. 2003). BMP-4 has been shown to be important for sperm quality with heterozygous mutation of Bmp4 resulting in diminished sperm counts and motility ( $\mathrm{Hu}$ et al. 2004). This demonstrates a great diversity of actions by these closely related BMPs and demonstrates how they can have vastly different functions under different conditions including the presence or absence of gonadotrophin stimulation.

Gene expression of $B m p 7$ was highest in immature testis, lowest during early puberty and then 
significantly increased during late puberty and more so in adult testis. This suggests upon translation BMP-7 may have a role in the initiation of germ cell proliferation and maintenance of late stage spermatogenesis. Our findings are in agreement with Zhao et al. (2001) who found abundant expression of $B m p 7$ in spermatogonia of immature mice, while in adult mice $B m p 7$ mRNA was found mainly in spermatids and suggested to have a supporting role for maintenance of spermatogenesis. Similar to Zhao et al. (1998) we found Bmp8a was significantly less expressed than $B m p 8 b$ in pubertal testis but not in adult testis. This supports the suggestions that BMP-8a is important in late stage spermatogenesis with mRNA being identified in round spermatids (Zhao et al. 1998), while BMP-8b was shown to be necessary for both initiation and maintenance of spermatogenesis being expressed in spermatogonia and spermatids of pubertal mice and at high levels in round spermatids of adult mice (Zhao and Hogan 1996).

In humans $B M P 3 B$ (GDF10) mRNA has been detected in the testis (Hino et al. 1996) and by using in-silico expression analysis Katoh and Katoh (2006) identified $B M P 3 B$ in human testis but reported the gene absent in mouse testis. We found low-level expression of $B m p 3$ and significantly higher expression of $B m p 3 b$ in all age groups. Bmp3b expression was highest in immature mice, reduced significantly during early puberty and late puberty and remained unchanged in adult testis. Based on its expression patterns we hypothesis $B m p 3 b$ may have a role in germ cell proliferation while factors released from spermatids and/or spermatozoa present at 6 weeks of age (Seok et al. 2004) may down regulate its expression.

Bmp5 mRNA has been detected in adult mouse spermatogonia (Marker et al. 1997) and of interest Bmp5 was the only gene we tested that had a lower expression at 2 weeks than all other age groups and increased significantly between 4 and 6 weeks which suggests a possible role in late stage spermatogenesis. Bmp6 has been reported to be expressed in mature mouse testis (Lyons et al. 1989), and in our study Bmp6 expression stayed relatively high compared with other BMP genes indicating a likely role in testicular functioning. We also detected Bmp15 mRNA in mouse testis, which was previously not detected using Northern blotting (Dube et al. 1998). Compared to other BMP genes, Bmp15 was expressed at a low level throughout development.

In humans $B M P R 2$ and BMP15 mRNAs have been detected in the testis (Rosenzweig et al. 1995, Aaltonen et al. 1999), and BMPRIB expression was shown to be elevated in testicular cancer (Fustino et al. 2011). As the expression of BMPs is widespread in the testis, over-expression of receptors is likely to result in heightened sensitivity to low expressed ligands resulting in altered cell responses. Altered expression of BMPs is also characteristic of prostate cancers (Harris et al. 1994, Barnes et al. 1995, Buijs et al. 2007). Given that altered BMPR-1B signaling by putative BMPs is implicated in reproductive cancers including testicular cancer (Miyazaki et al. 2004, Bokobza et al. 2009, Fustino et al. 2011, Neumann et al. 2011), which is one of the most common cancers affecting young Caucasian men in developed countries (Rosen et al. 2011), a mouse model profiling the postnatal expression of BMP and BMP receptor genes in the testis may be useful for understanding normal physiology and provide a comparison for altered physiology in cancerous tissues.

This study establishes an extensive BMP system in mouse testis throughout postnatal development at the mRNA level. Further examination of BMP and BMP receptor mRNAs in Leydig cells, Sertoli cells and germ cells will need to be carried out to elucidate what their individual roles are likely to be. Additionally, studies of protein expression will be needed to confirm the translation and abundance of the BMP and BMP receptor proteins not already detected. Given the predominance of BMP and BMP receptor genes reported in our study, and based on available research findings, it is likely that many of these genes have vital roles in germ and somatic cell proliferation, cellular homeostasis and steroid production, aspects we are currently investigating.

\section{Conflict of Interest}

There is no conflict of interest.

\section{Acknowledgements}

We would like to thank Mr. Kim Quinn, from the Department of Primary Industries, for his expertise, training, advice and assistance in use of the robot and qPCR thermocycler. We would also like to thank Ms Janelle McFarlane from the Physiology Animal House at UNE for the provision and care of laboratory mice needed for this study. Ilona Ciller, $\mathrm{PhD}$ and Ursula Ciller, PhD were supported by Australian Postgraduate Awards. 


\section{References}

AALTONEN J, LAITINEN MP, VUOJOLAINEN K, JAATINEN R, HORELLI-KUITUNEN N, SEPPA L, LOUHIO H, TUURI T, SJOBERG J, BUTZOW R, HOVATTA O, DALE L, RITVOS O: Human growth differentiation factor 9 (GDF-9) and its novel homolog GDF-9B are expressed in oocytes during early folliculogenesis. $J$ Clin Endocrinol Metab 84: 2744-2750, 1999.

AOKI H, FUJII M, IMAMURA T, YAGI K, TAKEHARA K, KATO M, MIYAZONO K: Synergistic effects of different bone morphogenetic protein type I receptors on alkaline phosphatase induction. J Cell Sci 114: 1483$1489,2001$.

BARNES J, ANTHONY CT, WALL N, STEINER MS: Bone morphogenetic protein-6 expression in normal and malignant prostate. World J Urol 13: 337-343, 1995.

BELVILLE C, JAMIN SP, PICARD JY, JOSSO N, DI CLEMENTE N: Role of type I receptors for anti-Mullerian hormone in the SMAT-1 Sertoli cell line. Oncogene 24: 4984-4992, 2005.

BEPPU H, KAWABATA M, HAMAMOTO T, CHYTIL A, MINOWA O, NODA T, MIYAZONO K: BMP type II receptor is required for gastrulation and early development of mouse embryos. Dev Biol 221: 249-258, 2000.

BOKOBZA SM, YE L, KYNASTON E, MANSEL RE, JIANG WG: Reduced expression of BMPR-IB correlates with poor prognosis and increased proliferation of breast cancer cells. Cancer Genomics Proteomics 6: 101-108, 2009.

BUIJS JT, RENTSCH CA, VAN DER HORST G, VAN OVERVELD PGM, WETTERWALD A, SCHWANINGER R, HENRIQUEZ NV, TEN DIJKE P, BOROVECKI F, MARKWALDER R, THALMANN GN, PAPAPOULOS SE, PELGER RCM, VUKICEVIC S, CECCHINI MG, LOWIK CWGM, VAN DER PLUIJM G: BMP7, a putative regulator of epithelial homeostasis in the human prostate, is a potent inhibitor of prostate cancer bone metastasis in vivo. Am J Pathol 171: 1047-1057, 2007.

CSBC: Protocols/Gene Expression/RNA extraction and quality control:/RNA quality control/Protocol - ethidium bromide Medium to large-scale RNA extractions. Cambridge Systems Biology Centre CSBC - FlyChip. Accessed 2011 at http://www.flychip.org.uk/ Updated 6/9/2011.

DEWULF N, VERSCHUEREN K, LONNOY O, MOREN A, GRIMSBY S, VANDE SPIEGLE K, MIYAZONO K, HUYLEBROECK D, TEN DIJKE P: Distinct spatial and temporal expression patterns of two type I receptors for bone morphogenetic proteins during mouse embryogenesis. Endocrinology 136: 2652-2663, 1995.

DUBE JL, WANG P, ELVIN J, LYONS KM, CELESTE AJ, MATZUK MM: The bone morphogenetic protein 15 gene is X-linked and expressed in oocytes. Mol Endocrinol 12: 1809-1817, 1998.

EBISAWA T, TADA K, KITAJIMA I, TOJO K, SAMPATH TK, KAWABATA M, MIYAZONO K, IMAMURA T: Characterization of bone morphogenetic protein-6 signaling pathways in osteoblast differentiation. $J$ Cell Sci 112: 3519-3527, 1999.

FUSTINO N, RAKHEJA D, ATEEK CS, NEUMANN JC, AMATRUDA JF: Bone morphogenetic protein signaling activity distinguishes histological subsets of pediatric germ cell tumors. Int J Androl 34: 218-233, 2011.

GOUEDARD L, CHEN YG, THEVENET L, RACINE C, BORIE S, LAMARRE I, JOSSO N, MASSAGUE J, DI CLEMENTE N: Engagement of bone morphogenetic protein type IB receptor and Smad1 signaling by antiMullerian hormone and its type II receptor. J Biol Chem 275: 27973-27978, 2000.

HARRIS SE, HARRIS MA, MAHY P, WOZNEY J, FENG JQ, MUNDY GR: Expression of bone morphogenetic protein messenger RNAs by normal rat and human prostate and prostate cancer cells. Prostate 24: 204-211, 1994.

HINO J, TAKAO M, TAKESHITA N, KONNO Y, NISHIZAWA T, HATSUO H, KANGAWA K: cDNA cloning and genomic structure of human bone morphogenetic protein-3B BMP-3b. Biochem Biophys Res Commun 223: 304-310, 1996.

HOODLESS PA, HAERRY T, ABDOLLAH S, STAPLETON M, O'CONNOR MB, ATTISANO L, WRANA JL: MADR1, a MAD-related protein that functions in BMP2 signaling pathways. Cell 85: 489-500, 1996.

HU J, CHEN YX, WANG D, QI X, LI TG, HAO J, MISHINA Y, GARBERS DL, ZHAO GQ: Developmental expression and function of Bmp4 in spermatogenesis and in maintaining epididymal integrity. Dev Biol 276: $158-171,2004$. 
ITMAN C, LOVELAND KL: SMAD expression in the testis: an insight into BMP regulation of spermatogenesis. Dev Dyn 237: 97-111, 2008.

KATOH Y, KATOH M: Comparative integromics on BMP/GDF family. Int J Mol Med 17: 951-955, 2006.

KERSTEN C, SIVERTSEN EA, HYSTAD ME, FORFANG L, SMELAND EB, MYKLEBUST JH: BMP-6 inhibits growth of mature human B cells; induction of Smad phosphorylation and upregulation of Id1. BMC Immunol 6: $9,2005$.

KOENIG BB, COOK JS, WOLSING DH, TING J, TIESMAN JP, CORREA PE, OLSON CA, PECQUET AL, VENTURA F, GRANT RA, CHEN GX, WRANA JL, MASSAGUE J, ROSENBAUM JS: Characterization and cloning of a receptor for BMP-2 and BMP-4 from NIH 3T3 cells. Mol Cell Biol 14: 5961-5974, 1994.

LIU FL, HATA A, BAKER JC, DOODY J, CARCAMO J, HARLAND RM, MASSAGUE J: A human Mad protein acting as a BMP-regulated transcriptional activator. Nature 381: 620-623, 1996.

LYONS K, GRAYCAR JL, LEE A, HASHMI S, LINDQUIST PB, CHEN EY, HOGAN BLM, DERYNCK R: Vgr-1, a mammalian gene related to Xenopus $\mathrm{Vg}-1$, is a member of the transforming growth factor $\beta$ gene superfamily. Proc Natl Acad Sci U S A 86: 4554-4558, 1989.

MARKER PC, SEUNG K, BLAND AE, RUSSELL LB, KINGSLEY DM: Spectrum of Bmp5 mutations from germline mutagenesis experiments in mice. Genetics 145: 435-443, 1997.

MCDONALD NQ, HENDRICKSON WA: A structural superfamily of growth factors containing a cysteine knot motif. Cell 73: 421-424, 1993

MISHINA Y, SUZUKI A, UENO N, BEHRINGER RR: Bmpr encodes a type I bone morphogenetic protein receptor that is essential for gastrulation during mouse embryogenesis. Gene Dev 9: 3027-3037, 1995.

MIYAZAKI H, WATABE TTK, MIYAZONO K: BMP signals inhibit proliferation and in vivo tumor growth of androgen-insensitive prostate carcinoma cells. Oncogene 23: 9326-9335, 2004.

NEUMANN JC, CHANDLER GL, DAMOULIS VA, FUSTINO NJ, LILLARD K, LOOIJENGA L, MARGRAF L, RAKHEJA D, AMATRUDA JF: Mutation in the type IB bone morphogenetic protein receptor alk6b impairs germ-cell differentiation and causes germ-cell tumors in zebrafish. Proc Natl Acad Sci U S A 108: 1315313158, 2011.

NISHIMURA R, KATO Y, CHEN D, HARRIS SE, MUNDY GR, YONEDA T: Smad5 and DPC4 are key molecules in mediating BMP-2-induced osteoblastic differentiation of the pluripotent mesenchymal precursor cell line C2C12. J Biol Chem 273: 1872-1879, 1998.

PELLEGRINI M, GRIMALDI P, ROSSI P, GEREMIA R, DOLCI S: Developmental expression of BMP4/ALK3/SMAD5 signaling pathway in the mouse testis: a potential role of BMP4 in spermatogonia differentiation. J Cell Sci 116: 3363-3372, 2003.

PIPER L, BINDON BM: Genetic segregation for fecundity in Booroola Merino sheep. In: Proceedings of the World Congress on Sheep and Beef Cattle Breeding. BARTON RA, SMITH WC (eds), Dunmore Press, Palmerston North, 1982, pp 395-400.

PUGLISI R, MONTANARI M, CHIARELLA P, STEFANINI M, BOITANI C: Regulatory role of BMP2 and BMP7 in spermatogonia and Sertoli cell proliferation in the immature mouse. Eur J Endocrinol 151: 511-520, 2004.

ROSEN A, JAYRAM G, DRAZER M, EGGENER SE: Global trends in testicular cancer incidence and mortality. Eur Urol 60: 374-379, 2011.

ROSENZWEIG BL, IMAMURA T, OKADOME T, COX GN, YAMASHITA H, TEN DIJKE P, HELDIN CH, MIYAZONO K: Cloning and characterization of a human type II receptor for bone morphogenetic proteins. Proc Natl Acad Sci U S A 92: 7632-7636, 1995.

ROSS A, MUNGER S, CAPEL B: Bmp7 regulates germ cell proliferation in mouse fetal gonads. Sex Dev 1: 127-137, 2007.

RUOSS C, TADROS A, O’SHEA T, MCFARLANE JR, ALMAHBOBI G: Ovarian follicle development in Booroola sheep exhibiting impaired bone morphogenetic protein signaling pathway. Reproduction 138: 689-696, 2009.

SEOK OS, AHN JM, MAYO KE, CHO BN: Developmental changes in inhibin- $\alpha$ gene expression in the mouse testis. Mol Cells 17: 67-72, 2004. 
SETTLE S, MARKER P, GURLEY K, SINHA A, THACKER A, WANG Y, HIGGINS K, CUNHA G, KINGSLEY DM: The BMP family member Gdf7 is required for seminal vesicle growth, branching morphogenesis, and cytodifferentiation. Dev Biol 234: 138-150, 2001.

TEIXEIRA J, FYNN-THOMPSON E, PAYNE AH, DONAHOE PK: Mullerian-inhibiting substance regulates androgen synthesis at the transcriptional level. Endocrinology 140: 4732-4738, 1999.

TEN DIJKE P, YAMASHITA H, ICHIJO H, FRANZEN P, LAIHO M, MIYAZONO K, HELDIN CH: Characterization of type I receptors for transforming growth factor-beta and activin. Science 264: 101-104, 1994.

WILSON T, WU XY, JUENGEL JL, ROSS IK, LUMSDEN JM, LORD EA, DODDS KG, WALLING GA, MCEWAN JC, O'CONNELL AR, MCNATTY KP, MONTGOMERY GW: Highly prolific Booroola sheep have a mutation in the intracellular kinase domain of bone morphogenetic protein IB receptor (ALK-6) that is expressed in both oocytes and granulosa cells. Biol Reprod 64: 1225-1235, 2001.

YAN C, WANG P, DEMAYO J, DEMAYO FJ, ELVIN JA, CARINO C, PRASAD SV, SKINNER SS, DUNBAR BS, DUBE JL, CELESTE AJ, MATZUK MM: Synergistic roles of bone morphogenetic protein 15 and growth differentiation factor 9 in ovarian function. Mol Endocrinol 15: 854-866, 2001.

YE J, COULOURIS G, ZARETSKAYA I, CUTCUTACHE I, ROZEN S, MADDEN TL: Primer-BLAST: a tool to design target-specific primers for polymerase chain reaction. BMC Bioinformatics 13: 134, 2012.

YI SY, LAPOIT PS, YOON BS, CHEN JYC, LU JKH, LYONS KM: The type I BMP receptor BmprIB is essential for female reproductive function. Proc Natl Acad Sci U S A 98: 7994-7999, 2001.

ZHAO GQ, HOGAN BLM: Evidence that mouse Bmp8a Op2 and Bmp8b are duplicated genes that play a role in spermatogenesis and placental development. Mech Dev 57: 159-168, 1996.

ZHAO GQ, DENG K, LABOSKY PA, LIAW L, HOGAN BLM: The gene encoding bone morphogenetic protein 8B is required for the initiation and maintenance of spermatogenesis in the mouse. Gene Dev 10: 1657-1669, 1996.

ZHAO GQ, LIAW L, HOGAN LM: Bone morphogenetic protein $8 \mathrm{~A}$ plays a role in the maintenance of spermatogenesis and the integrity of the epididymis. Development 125: 1103-1112, 1998.

ZHAO GQ, CHEN YX, LIU XM, XU Z, QI X: Mutation in Bmp7 exacerbates the phenotype of Bmp8a mutants in spermatogenesis and epididymis. Dev Biol 240: 212-222, 2001. 